\title{
PENGEMBANGAN MODUL AJAR BERBASIS MODEL PROJECT BASED LEARNING (PjBL) YANG PRAKTIS BAGI MAHASISWA CALON GURU FISIKA
}

\author{
Oleh \\ Lia Purnama Sari ${ }^{1)}$; Itgo Hatchi ${ }^{2)}$; Dwi Aninditya Siregar ${ }^{3)}$ \\ ${ }^{1}$ liasari2808@gmail.com \\ 2hatchiitgo@gmail.com \\ 32wi.aninditya@gmail.com \\ ${ }^{1,2,3}$ Dosen Institut Pendidikan Tapanuli Selatan
}

\begin{abstract}
Abstrak
Penelitian ini merupakan penelitian pengembangan atau research and development. Research and development adalah metode penelitian yang dipakai dalam menghasilkan produk tertentu dan menguji kepraktisan dan keefektifan produk. Penelitian ini bertujuan dalam mengembangkan modul ajar berbasis project based learning (PjBL) yang praktis. Subjek penelitian yang digunakan adalah modul ajar berbasis PjBL. Dosen dan mahasiswa program studi pendidikan fisika Institut Pendidikan Tapanuli Selatan merupakan responden dalam penelitian pengembangan modul ajar berbasis PjBL ini. Responden akan mengisi angket praktikalitas untuk mengetahui kepraktisan dari modul ajar yang dikembangkan. Berdasarkan penelitian pengembangan dan uji coba yang telah dilaksanakan dengan menggunakan modul ajar berbasis PjBL bagi mahasiswa calon guru fisika dapat disimpulkan bahwa modul ajar yang dikembangkan dalam penelitian ini adalah modul ajar yang dikategorikan pada modul ajar valid dan praktis. Kepraktisan dari modul ajar ini dilihat dari respon dosen dan mahasiswa yang menggunakannya dengan penilaian praktis.
\end{abstract}

Kata Kunci : Modul Ajar, Project Based Learning (PjBL)

\section{PENDAHULUAN}

Pendidikan adalah upaya terencana ataupun tidak untuk mewujudkan potensi diri peserta didik guna memiliki kecerdasan intelektual, emosional, dan spiritual. Pendidikan dapat membentuk akhlak dan menumbuhkan keterampilan yang diperlukan dalam kehidupan dan bermasyarakat. Untuk mencapai hal tersebut perlu diadakan proses pembelajaran yang melibatkan mahasiswa. Proses pembelajaran merupakan suatu hal yang harus dilakukan oleh tenaga pendidik. Mahasiswa yang mempelajari sesuatu dapat menemukan makna yang akan membawa mahasiswa ke arah yang baik. Dengan demikian, motivasi mahasiswa untuk belajar disebabkan adanya pembelajaran bermakna dan menyenangkan. Mahasiswa program studi Pendidikan Fisika di Institut Pendidikan Tapanuli Selatan Kota Padangsidimpuan adalah mahasiswa yang nantinya akan menjadi guru fisika di sekolah. Ini menunjukkan dinamika dunia pendidikan fisika yang akan datang ditentukan oleh mereka. Masa sekarang proses pembelajaran fisika masih kurang bermakna, sehingga pelajaran fisika di sekolah terasa membosankan, karena itulah mahasiswa pendidikan fisika yang masih di bangku kuliah memperbaiki keadaan yang kurang bermakna tersebut.

Mahasiswa calon guru fisika sebaiknya memiliki kemampuan dan keterampilan dalam melaksanakan proses pembelajaran yang bermutu. Pembelajaran yang dapat mengaktifkan mahasiswa serta mampu meningkatkan potensi dirinya adalah menggunakan model Project Based Learning (PjBL) atau pembelajaran berbasis proyek. Menurut Titu (2015) Project Based Learning adalah merupakan salah satu model pembelajaran yang mencoba mengaitkan antara teknologi dengan masalah kehidupan sehari-hari yang akrab dengan proyek sekolah. sedangkan menurut Kristanti (2016) model pembelajaran berbasis proyek (Project Based Learning) merupakan pembelajaran yang berpusat pada proses, relatif berjangka waktu, berfokus pada masalah, unit pembelajaran bermakna dengan memadukan konsep-konsep dari sejumlah komponen baik itu pengetahuan, disiplin ilmu atau lapangan $\mathrm{PjBL}$ inidapat menstimulasi motivasi, proses, dan meningkatkan kompetensi belajar mahasiswa. Model PjBL yang diberikan kepada mahasiswa merupakan langkah awal dalam mengumpulkan dan mengintegrasikan pengetahuan baru berdasarkan pengalaman dalam berkativitas, dan menuntut mahasiswa untuk melakukan kegiatan merancang, investigasi, memecahkan masalah, membuat keputusan, dan memberikan kesempatan pada mahasiswa bekerja secara kelompok ataupun mandiri.

Model PjBL ini digunakan dalam pengembangan modul ajar pada mata kuliah di program studi pendidikan fisika. Pengembangan modul ajar berbasis model $\mathrm{PjBL}$ diharapkan dapat membantu mahasiswa calon guru fisika. Menurut Sudjana dan Rivai (2007:132) modul merupakan jenis kesatuan kegiatan belajar yang terencana, dirancang untuk membantu para siswa secara 
individual dalam mencapai tujuan-tujuan belajarnya. Modul sebagai media pembelajaran memiliki ciri sebagai paket yang dirancang oleh pernyataan tujuan belajar yang dapat mengajak keikutsertaan siswa secara aktif dalam proses pembelajaran. Modul juga mencantumkan sistem penilaian berdasarkan keterampilan dan penguasaan mahasiswa, dan juga memuat materi perkuliahan, percobaan, proyek mahasiswa dan tugas mahasiswa. Dengan menggunakan modul ajar yang berbasis $\mathrm{PjBL}$ ini dapat memberi peluang bagi mahasiswa untuk mengembangkan potensi dirinya dalam menghasilkan sebuah karya atau produk. Modul ajar berbasis PjBL ini dapat mempermudah mahasiswa dalam memahami materi yang sulit karena di dalam modul ajar ini materi yang dijabarkan disusun secara ringkas dan padat. Dengan keadaan tersebut penulis tertarik melakukan penelitian pengembangan modul ajar berbasis Project Based Learning (PjBL) bagi mahasiswa calon guru fisika di Kota Padangsidimpuan.

\section{METODE PENGEMBANGAN}

Penelitian ini merupakan penelitian pengembangan atau research and development . Sugiyono (2008) mengemukakan bahwa penelitian dan pengembangan adalah metode penelitian yang digunakan dalam menghasilkan sebuah produk tertentu dan menguji kepraktisan dan keefektifan produk tersebut. Model penelitian yang digunakan adalah model pengembangan four-D (4D) models. Tahapan dari 4D models ini adalah tahap pendefinisian (define), tahap perancangan (design), tahap pengembangan (develop), dan tahap penyebaran (disseminate). Tahap pendefinisian terdiri dari dua langkah yaitu analisis materi dan analisis mahasiswa. Untuk tahap perancangan pada modul ajar diawali dengan penulisan, penelaahan dan pengeditan pada modul ajar yang disusun. Sedangkan tahap pengembangan bertujuan untuk menghasilkan modul ajar fisika dasar berbasis $\mathrm{PjBL}$ yang telah direvisi berdasarkan masukan dan hasil diskusi dari pakar, sehingga di dapat modul ajar yang valid dan praktis. Tahap penyebaran dilakukan di dalam kelas sama dengan langkah pada kelas uji coba. Modul ajar ini digunakan oleh peneliti untuk diajarkan di kelas tersebut.

Subjek penelitian yang digunakan adalah modul ajar berbasis PjBL. Sedangkan responden dalam penelitian ini adalah dosen dan mahasiswa Program Studi Pendidikan Fisika Institut Pendidikan Tapanuli Selatan yang berjumlah 13 orang. Responden akan mengisi angket praktikalitas untuk mengetahui kepraktisan dari modul ajar yang dikembangkan.
Instrumen merupakan suatu alat yang digunakan untuk mendapatkan data atau informasi untuk menguji kevalidan dan kepraktisan modul ajar yang disusun. Instrumen yang digunakan dalam penelitian ini adalah:

a. Angket Respon Dosen Terhadap Modul Ajar

Angket respon dosen digunakan untuk memperoleh respon dosen terhadap modul ajar yang dikembangkan termasuk praktis atau tidak. Angket ini diisi oleh dosen setelah menelaah dan menggunakan modul ajar dalam perkuliahan.

b. Angket Respon Dosen Terhadap
Keterlaksanaan SAP

Angket ini digunakan untuk mengetahui apakah SAP yang disusuk terlaksana dengan baik selama perkuliahan dan juga mengetahui bahwa SAP yang digunakan pktis atau tidak dalam penerapannya di kelas.

c. Angket Respon Mahasiswa Terhadap Modul Ajar

Angket respon mahasiswa diisi oleh mahasiswa itu sendiri untuk mendapatkan respon ataupun tanggapan mahasiswa dari modul ajar ulyang digunakan saat perkuliahan. data respon mahasiswa ini akan diketahui kepraktisan dari modul ajar yang telah dikembangkan dan digunakan.

Analisis data hasil penelitian dilakukan untuk mengetahui praktikalitas modul ajar yang telah dibuat dan dikembangkan. Data penelitian dianalisis menggunakan metode statistik deskritif untuk mendaatkan iali rata-rata dan persentase. Perhitungan data nilai akhir dari praktikalitas dianalisis menggunakan rumus

$$
P=\frac{X}{Y} \times 100 \%
$$

$\begin{array}{lll}\text { Keterangan: } & \mathrm{P} & \text { : Nilai Praktikalitas } \\ & \mathrm{X} & \text { : Perolehan Skor } \\ & \mathrm{Y} & \text { : Skor Maksimum }\end{array}$

Kategori praktikalitas bahan ajar berdasarkan nilai akhir yang didapatkan dapat dilihat pada Tabel 1 .

Tabel 1. Kategori dan Interval Praktikalitas Produk

\begin{tabular}{|c|c|}
\hline Interval & Kategori \\
\hline $0-20$ & Sangat tidak praktis \\
\hline $21-40$ & Tidak praktis \\
\hline $41-60$ & Kurang praktis \\
\hline $61-80$ & Praktis \\
\hline $81-100$ & Sangat praktis \\
\hline
\end{tabular}

(Dimodifikasi dari Riduwan, 2009)

\section{HASIL DAN PEMBAHASAN}

Analisis Data dan Hasil Pengembangan

Tahap ini menyajikan hasil pengembangan modul ajar berbasis PjBL di Institut Pendidikan 
Tapanuli Selatan. Mata kuliah yang digunakan dalam pengembangan modul ajar ini adalah Fisika Dasar 2 materi arus bolak-balik. Langkah pengembangan ini dimulai dari analisis materi sampai dengan praktikalitas modul ajar. Setelah melakukan pengumpulan data penelitian, maka data tersebut dideskripsikan. Deskripsi data penelitian dijelaskan sebagai berikut:

\section{Tahap Pendefinisian (Define)}

Tahap pendefinisian adalah hasil analisis terhadap materi dan mahasiswa. Hasil analisis materi yang dilakukan dijadikan dasar untuk menentukan konsep pada materi arus bolak-balik. Konsep dari materi arus bolak-balik diterapkan sesuai dengan model PjBL. Model ini digunakan untuk meningkatkan aktivitas dan kompetensi mahasiswa. Sedangkan analisis mahasiswa dilakukan untuk mengetahui karakteristk mahasiswa yang meliputi minat, sikap, gaya belajar yang ada pada mahasiswa. Karakteristik ini dijadikan acuan untuk mengembangkan modul ajar. Hasil analisis menunjukkan bahwa mahasiswa kurang aktif dalam perkuliahan ataupun diskusi kelas, kemampuan mahasiswa dalam membuat produk yang berhubungan dengan materi fisika dasar kurang dikembangkan. Mahasiswa masih sulit dalam memecahkan masalah yang ada pada materi kuliah karena materi yang dijabarkan terlalu rumit. Kemudian mahasiswa juga jarang mengulang materi kuliah kembali di rumah.

\section{Tahap Perancangan (design)}

Berdasarkan kekurangan dan kelebihan dari materi dan mahasiswa maka dapat dirancang bahan ajar untuk menunjang pelaksanaan perkuliahan yang sesuai dengan KKNI yang diterapkan di institusi. Bahan ajar yang dirancang berupa modul ajar berbasis project based learning (PjBL). Modul ajar terdiri dari bagian sampul yang berisi identitas modul meliputi judul materi, sasaran pengguna, dan penulis modul. Gambar yang ada di sampul sesuai dengan materi yang ada pada modul. Selanjutnya halaman isi berisi materi kuliah per pertemuan, latihan, percobaan dan proyek.

\section{Tahap Pengembangan (develop)}

Tahap pengembangan merupakan tahap untuk menghasilkan modul ajar berbasis PjBL yang valid dan praktis sehingga baik untuk digunakan dalam perkuliahan. Hasil penilaian dari validator dan data dari angket respon dosen dan mahasiswa digunakan sebagai acuan untuk penilaian validasi dan praktikalitasnya. Hasil validasi yang diberikan oleh validator untuk modul ajar berbasis $\mathrm{PjBL}$ dapat dilihat pada Tabel 2 .
Tabel 2. Hasil analisis Validasi Modul Ajar

\begin{tabular}{|c|c|c|}
\hline \multirow{2}{*}{ Indikator } & \multicolumn{2}{|c|}{ Penilaian Validator (\%) } \\
\hline & SAP & Modul Ajar \\
\hline Isi & 85 & 91,6 \\
\hline Konstuksi & 75 & 87,5 \\
\hline Komponen Bahasa & 81 & 85,7 \\
\hline Rerata (\%) & 80,3 & 88,3 \\
\hline Kategori & Valid & Sangat Valid \\
\hline
\end{tabular}

penilaian validator untuk modul ajar menunjukkan bahwa produk yang dirancang dikategorikan sangat valid. Hasil validasinya teretak pada persentase $88,3 \%$ untuk modul ajar dan $80,3 \%$ untuk SAP. Hasil analisis ini disimpulkna bahwa modul ajar berbasis PjBL yang dirancang sangat valid.

\section{Praktikalitas Modul Ajar}

Nilai praktikalitas modul ajar dilihat dari penilaian angket respon dosen dan angket respon mahasiswa. Dari angket respon dosen didapatkan penilaian dengan rata-rata persentase $85 \%$ terletak pada kategori sangat praktis. Sedangkan penilaian dari angket respon mahasiswa didapatkan rata-rata persentase $78 \%$ dengan kategori praktis. Hasil angket respon ini dapat dilihat pada Tabel 3.

Tabel 3. Analisis Angket Respon Terhadap Modul

\begin{tabular}{|l|c|c|}
\hline \multirow{2}{*}{\multicolumn{1}{|c|}{ Pernyataan }} & \multicolumn{2}{c|}{ Angket Respon } \\
\cline { 2 - 3 } & Dosen & Mahasiswa \\
\hline Jumlah Skor & 51 & 282 \\
\hline Skor Maksimum & 60 & 364 \\
\hline Rata-rata Persentase & $85 \%$ & $78 \%$ \\
\hline Kategori & Sangat Praktis & Praktis \\
\hline
\end{tabular}

Berdasarkan respon dari angket yang diberikan pada dosen dan mahasiswa didapatkan bahwa modul ajar berbasis PjBL yang dikembangkan praktis dalam penggunaannya, sehingga perkuliahan dengan modul ajar berbasis $\mathrm{PjBL}$ ini dapat meningkatkan potensi diri yang ada pada mahasiswa.

\section{Pembahasan}

Pengembangan modul ajar berbasis $\mathrm{PjBL}$ bagi mahasiswa calon guru fisika ini diawali dengan tahap pendefinisian (define). Tahap pendefinisian ini merupakan tahap analisis materi dan analisis mahasiswa. dari analisis tersebut didapatkan hasil analisis bahwa mahasiswa fisika Institut Pendidikan Tapanuli Selatan dalam perkuliahan belum menampakkan keaktifan saat perkuliahan. Mahasiswa juga belum giat dalam menghasilkan sebuah produk yang berhubungan dengan materi fisika dasar. Saat kegiatan diskusipun, masih ada mahasiswa yang tidak aktif atau jarang terlibat dalam tanya jawab atau menyampaikan hasil diskusi.

Tahap selanjutnya adalah tahap perancangan (design) modul ajar. tahap perancangan dilakukan setelah memperoleh data dari tahap pendefinisian. pada tahap perancangan ini, langkah-langkah yang harus dilakukan adalah 
memvalidasi modul ajar kepada pakar. Hasil validasi pada tahap perancangan digunakan untuk acuan dalam penyusunan modul ajar yang valid dan bisa digunakan dalam proses perkuliahan. hasil validasi dari validator menunjukkan bahwa modul ajar berbasis PjBL yang dikembangakn sangat valid dan layak untuk digunakan. Langkah selanjutnya adalah tahap pengembangan (develop) yang termasuk di dalamnya adalah uji praktikalitas modul ajar.

Praktikalitas modul ajar berhubungan dengan kemudahan penggunaan bahan ajar oleh dosen dan mahasiswa dalam proses perkuliahan. berdasarkan hasil analisis data dari angket respon dosen dan mahasiswa, modul ajar berbasis $\mathrm{PjBL}$ yang dikembangkan tergolong pada kategori sangat praktis. Hal ini sesuai dengan Permendikbud No. 103 Tahun 2014 tentang RPP dan bahan ajar yang digunakan dalam proses pembelajaran. Kepraktisan ini dilihat dari kemudahan dalam penggunaan, waktu yang diperlukan, dan daya tarik dari modul ajar tersebut. modul ajar berbasis $\mathrm{PjBL}$ ini dikembangkan untuk memudahkan mahasiswa dalam memahami materi fisika dasar khususnya materi arus bolak-balik. modul ajar berbasis PjBL ini juga dilengkapi dengan kegiatan mahasiswa dalam membuat percobaan dan membuat proyek.

Kegiatan yang ada di dalam modul ajar akan meningkatkan aktivitas dan kreatifitas mahasiswa dalam perkuliahan. Sejalan dengan peneltian yang telah dilakukan, modul ajar ini diharapkan dapat mengembangkan kemampuan mahasiswa dalam menyelesaikan proyek dan menghasilkan sebuah produk yang berhubungan dengan fisika. kemampuan mahasiswa yang dapat menciptakan produk ini akan berguna saat mahasiswa calon guru fisika terjun langsung ke lapangan atau mengajar di sekolah. Penerapan modul ajar berbasis PjBL ini dapat dirasakan manfaatnya oleh mahasiswa sehingga mereka mendapatkan makna yang mendalam dari apa yang dipelajarinya.

\section{SIMPULAN DAN SARAN}

\section{Simpulan}

Berdasarkan peelitian pengembangan dan uji coba yang telah dilaksanakan dengan menggunakan modul ajar berbasis PjBL bagi mahasiswa calon guru fisika dapat disimpulkan bahwa modul ajar yang dikembangkan dalam penelitian ini adalah modul ajar yang dikategorikan pada modul ajar valid dan praktis. kepraktisan dari modul ajar ini dilihat dari respon dosen dan mahasiswa yang menggunakannya dengan penilaian praktis.

\section{Saran-saran}

Berdasarkan pengembangan yang telah dilaksanakan, penulis menyarankan kepada peneliti lain untuk tidak hanya menggunakan modul ajar ini pada satu mata kuliah saja, diharapkan untuk peneliti lainnya dapat mengembangkan modul ajar berbasis PjBL ini pada mata kuliah lain.

\section{UCAPAN TERIMA KASIH}

Terima kasih kepada Kemenristek Dikti melalui Simlitabmas dari DP2M DIKTI yang telah memberikan dana dalam penelitian untuk tahun 2019.

\section{REFERENSI}

Depdikbud. 2003. Kurikulum Berbasis Kompetensi Mata Pelajaran Sains untuk SMP. Jakarta: Depdiknas.

Kristanti, Yulita Dyah. 2016. Model Pembelajaran Berbasis Proyek (Project Based Learning Model) Pada Pembelajaran Fisika di SMA. Jurnal Pembelajaran Fisika. Vol.5 No.2, September 2016, hal 122128

Sudjana, N. dan Ahmad R.2007. Teknologi Pengajaran. Bandung: CV. Sinar Baru Algesindo.

Sugiyono. 2009. Metode Penelitian Kuantitatif, Kualitatif dan $R \& D$. Bandung: Alfabeta.

Titu, Maria Anita. 2015. Penerapan Model Pembelajaran Project Based Learning (PjBL) Untuk Meningkatkan Kreativitas Siswa Pada Materi Konsep Masalah Ekonomi. Prosiding Seminar Nasional 9 Mei 2015. 